Jurnal Keperawatan Silampari

Volume 5, Nomor 1, Desember 2021

e-ISSN: 2581-1975

p-ISSN: 2597-7482

DOI: https://doi.org/10.31539/jks.v5i1.2368

\title{
TEKNIK RELAKSASI NAFAS DALAM TERHADAP PENINGKATAN SATURASI OKSIGEN PADA PASIEN PPOK
}

\author{
Ni Made Dwi Yunica Astriani ${ }^{1}$, Aditha Angga Pratama ${ }^{2}$, \\ Putu Wahyu Sri Juniantari Sandy ${ }^{3}$ \\ Sekolah Tinggi Ilmu Kesehatan Buleleng ${ }^{1,2,3}$ \\ pratamaaditha@gmail.com²
}

\begin{abstract}
ABSTRAK
Penelitian ini bertujuan untuk mengetahui pengaruh teknik relaksasi nafas dalam terhadap saturasi oksigen pada pasien PPOK. Desain penelitian menggunakan pra-eksperimental dengan rancangan one group pre-post test design. Hasil penelitian menunjukkan bahwa rata-rata nilai saturasi oksigen sebelum diberikan relaksasi nafas dalam 90,19 dan rata-rata nilai saturasi oksigen setelah diberikan relaksasi nafas dalam 93,27. Berdasarkan hasil dari uji paired t-test menunjukkan bahwa hasil pre dan post $(0,000)<\alpha(0,05)$. Simpulan, ada pengaruh teknik relaksasi nafas dalam terhadap peningkatan saturasi oksigen pada pasien PPOK.
\end{abstract}

Kata Kunci: PPOK, Saturasi Oksigen, Teknik Relaksasi Nafas Dalam

\begin{abstract}
This study aims to determine the effect of deep breathing relaxation techniques on oxygen saturation in COPD patients. The research design used a pre-experimental one-group prepost test design. The results showed that the average oxygen saturation value before being given deep breath relaxation was 90.19, and the average oxygen saturation after being given deep breath relaxation was 93.27. Based on the results of the paired t-test showed that the results of pre and post $(0.000)<(0.05)$. In conclusion, there is an effect of deep breathing relaxation techniques on increasing oxygen saturation in COPD patients.
\end{abstract}

Keywords: COPD, Oxygen Saturation, Deep Breathing Relaxation Technique

\section{PENDAHULUAN}

PPOK (Penyakit Paru Obstruksi Kronis) adalah kelainan paru yang ditandai dengan gangguan fungsi paru berupa memanjangnya periode ekspirasi yang disebabkan oleh adanya penyempitan saluran nafas dan tidak banyak mengalami perubahan dalam masa observasi beberapa waktu. PPOK merupakan penyakit yang disebabkan oleh kebiasaan merokok, polusi udara, infeksi. Tanda dan gejala PPOK mengalami sesak nafas yang bertambah ketika beraktivitas atau bertambah dengan meningkatnya usia disertai batuk berdahak atau pernah mengalami sesak nafas disertai batuk berdahak. Polusi udara baik dalam maupun luar ruangan seperti rokok, asap kompor, debu jalanan, gas beracun, kendaraan bermotor merupakan kejadian PPOK pada sektor pekerjaan wirasasta. Penelitian yang dilaukan oleh Kaur et al., (2018) meyatakan bahwa sebanyak 43,7 \% sebagian besar pekerjaan pada sektor wiraswasta. 
Kabuparen Buleleng menduduki peringkat ke 4 prevalensi merokok sebesar 19,85\% dengan jumlah perokok setiap harinya (Balitbangkes, 2019). Perokok aktif maupun pasif memiliki resiko lebih tinggi terhadap kejadian PPOK. Iritasi yang terus menerus akibat asap rokok dapat menyebabkan respon yang berlebih pada silia dan mukus di bronkus yang berfungsi sebagai pertahanan. Asap rokok dapat menghambat pembersihan mukosiliar (mucociliary clearance). Hal ini sesuai dengan penelitian yang dilakukan oleh Lukito (2019) sebesar 63,3 \% faktor resiko penyebab PPOK adalah karena merokok. Hipersekresi mukus menyebabkan penderita PPOK mengalami batuk dan sesak nafas. Berhenti merokok merupakan salah satu upaya untuk memperlambat buruknya PPOK. Berhenti merokok dapat menurunkan tingkat fungsi paru-paru dan memperlambat serangan kematian (Maunaturrohmah \& Yuswatiningsih, 2018).

Manajemen nonfarmakologi pada pasien PPOK sangat beragam seperti mencegah malnutrisi, rehabilitasi pulmoner dan berhenti merokok. Rehabilitasi pulmoner seperti lahitan nafas dapat mengurangi kesulitan bernafas dan mampu memperbaiki ketahanan otot yang disebabkan hiperinflasi paru pada pasien dengan PPOK (Lilyana, 2017; Padila et al., 2019; Harsismanto et al., 2020). Sintesis hasil penelitian yang dilakukan oleh Astriani et al., (2020); Padila et al., (2020) melakukan pelatihan tentang relaksasi nafas dengan menggunakan ballon blowing dan super bublles. Rerata terjadi peningkatan pengetahuan dan menurunkan sesak setelah diberikan terapi relaksasi nafas dengan nilai saturasi oksigen meningkat.

Studi pendahuluan yang dilakukan di Rumah Sakit Parama Sidhi didapatkan hasil dari wawancara dengan salah satu perawat menyatakan rata-rata frekuensi pernafasan pada pasien PPOK 28x/menit. Dari hasil observasi pada 5 pasien PPOK dengan dilakukan pemeriksaan saturasi oksigen menggunakan oksimetri yang dipasang pada jari telunjuk tangan kiri, didapatkan hasil saturasi oksigen perifer sebelum diberikan teknik relaksasi nafas dalam pada orang pertama 93\%, pada orang kedua 92\%, pada orang ketiga 93\%, pada orang keempat $90 \%$ dan pada orang kelima 92\%. Selama ini perawat hanya memberikan terapi oksigen untuk mencegah sesak nafas pada pasien PPOK.

Penelitian tentang saturasi ksigen pada pasien PPOK sudah pernah dilakukan, namun penelitian ini berfokus pada teknik relaksasi nafas dalam terhadap peningkatan saturasi oksigen pada pasien PPOK.

\section{METODE PENELITIAN}

Metode penelitian yang digunakan adalah dengan memberikan intervensi pada pasien PPOK. Pengumpulan data secara observasi dilakukan sebelum dan sesudah dilakukan intervensi teknik relaksasi nafas dalam, dengan melihat nilai saturasi oksigen penderita. Intervensi diberikan pada 26 pasien PPOK dengan teknik sampel total sampling dengan menggunakan desain penelitian yaitu one group pre-test dan post-test.

Melakukan pre test untuk mengetahui nilai saturasi oksigen pada pasien PPOK sebelum diberikan relaksasi nafas dalam. Setelah itu memberikan relaksasi nafas dalam pada pasien PPOK selama 5-10 menit. Dilakukan post test untuk melihat perubahan saturasi oksigen. Kaji etik dalam penelitian ini dilakukan oleh Komite Etik Penelitian Kesehatan (KEPK) Sekolah Tinggi Ilmu Kesehatan Buleleng. 


\section{HASIL PENELITIAN}

Tabel. 1

Distribusi Frekuensi

Berdasarkan Usia

\begin{tabular}{rcc}
\hline Umur & Jumlah & Persentase $(\%)$ \\
\hline$<30$ Tahun & 0 & 0 \\
$\geq 30$ Tahun & 26 & 100 \\
\hline Total & 26 & 100 \\
\hline
\end{tabular}

Berdasarkan tabel 1 menunjukkan bahwa sebagian besar responden berumur lebih daro 30 tahun yaitu sebesar $100 \%$.

Tabel. 2

Distribusi Frekuensi

Berdasarkan Jenis Kelamin

\begin{tabular}{ccc}
\hline Usia & Frekuensi (f) & Persentase (\%) \\
\hline Laki-laki & 17 & 65,4 \\
Perempuan & 9 & 34,6 \\
\hline Total & 26 & 100 \\
\hline
\end{tabular}

Berdasarkan tabel 2 menunjukkan bahwa distribusi frekuensi responden berdasarkan jenis kelamin sebagian besar responden berjenis kelamin laki-laki yaitu 17 orang $(65,4 \%)$ dan 9 orang $(34,6 \%)$ responden berjenis kelamin perempuan.

Tabel. 3

Saturasi oksigen Responden Sebelum Diberikan Relaksasi Nafas Dalam

\begin{tabular}{lcccccc}
\hline & $\mathrm{N}$ & Mean & Min & Max & SD & $95 \%$ CI \\
\hline Pre Test & 26 & 90,19 & 86 & 94 & 2,191 & $89,31-91,08$ \\
\hline
\end{tabular}

Berdasarkan tabel 3 menunjukkan bahwa rata-rata nilai saturasi oksigen pasien PPOK sebelum diberikan relaksasi nafas dalam dari 26 responden adalah 90,19 (95\% CI: 89,3191,08) dengan standar deviasi 2,191. Nilai saturasi oksigen terendah 86 dan tertinggi 94.

Tabel. 4

Saturasi Oksigen Responden Setelah Diberikan Relaksasi Nafas Dalam

\begin{tabular}{rcccccc}
\hline & $\mathrm{N}$ & Mean & Min & Max & SD & $95 \%$ CI \\
\hline Post test & 26 & 93,27 & 90 & 97 & 2,089 & $92,43-94,11$ \\
\hline
\end{tabular}

Berdasarkan tabel 4 menunjukkan bahwa rata-rata nilai saturasi oksigen setelah diberikan relaksasi nafas dalam dari 26 responden adalah 93,27 (95\% CI: 92,43-94,11) dengan standar deviasi 2,089. Nilai saturasi oksigen terendah 90 dan tertinggi 97. 
Tabel. 5

Hasil Analisis Pre dan Post Test dengan Menggunakan Program Komputer.

\begin{tabular}{lccccc}
\hline \multirow{2}{*}{ Variabel } & & & & \multicolumn{2}{c}{ Paired Differences } \\
\cline { 4 - 6 } & $\mathrm{n}$ & Mean $\pm \mathrm{SD}$ & CI 95\% & $\begin{array}{c}\text { Perbedaan } \\
\text { (Mean } \pm \text { SD) }\end{array}$ & $P$ \\
\hline Saturasi oksigen pre test & 26 & $90,19 \pm 2,191$ & $(3,533-$ & $3,077 \pm 1,129$ & 0,000 \\
Saturasi oksigen post test & 26 & $93,27 \pm 2,089$ & $2,621)$ & & \\
\hline
\end{tabular}

Berdasarkan tabel 5 menunjukkan bahwa ada pengaruh yang signifikan pada pelaksanaan intervensi relaksasi nafas dalam terhadap saturasi oksigen pasien PPOK. Hasil perhitungan dengan program komputer menunjukkan $p$ value $0,000(p<0,005)$. Maka dapat disimpulkan bahwa terdapat pengaruh relaksasi nafas dalam terhadap saturasi oksigen pasien PPOK.

\section{PEMBAHASAN}

\section{Karakteristik Responden}

Hasil penelitian ini menunjukan bahwa bahwa dari 26 subjek penelitian, mayoritas pasien PPOK berdasarkan usia ditemukan seluruhnya berada pada usia diatas 30 tahun (100\%). Hasil penelitian ini serupa dengan hasil penelitian lain yang menyatakan bahwa mayoritas pasien PPOK memiliki usia diatas 30 tahun. Penelitian oleh Astriani et al., (2020) rata-rata usia 46,54 dengan usia terendah yaitu 31 tahun dan tertinggi 60 tahun. Seseorang yang memiliki usia diatas 40 tahun memiliki resiko yang sangat besar mengalami gangguan pernafasan hal ini disebabkan oleh pola pernafasan dan perubahan bentuk yang terjadi karena meningkatnya usia seseorang (Wardani et al., 2019).

Hasil penelitian ini juga menunjukan bahwa mayoritas pasien PPOK adalah berjenis kelamin laki-lak. Hasil penelitian ini serupa dengan temuan penelitian sebelumnya yaitu Tarigan \& Juliandi (2018) dalam penelitiannya sebesar 80,6 \% penderita PPOK berjenis kelanin laki-laki sedangkan 19,4 \% berjenis kelamin perempuan. Laki-laki dalam hal ini memiliki gaya hidup yang berbeda dengan perempuan seperti merokok, lingkungan tempat kerja yang terbuka tentunya polusi udara ini yang merupakan faktor predisposisi penyakit PPOK sedangkan perempuan lebih banyak di rumah menjadi ibu rumah tangga.

\section{Nilai Saturasi Oksigen Sebelum Relaksasi Nafas Dalam}

Hasil penelitian ini menunjukan bahwa sebelum diberikan teknik relaksasi nafas dalam, ditemukan saturasi oksigen terendah adalah 86\% dan tertinggi adalah 94\% dengan rerata saturasi oksigen sebesar 90,19\%. Penelitian ini mendapatkan bahwa terdapat pasien PPOK yang memiliki nilai saturasi oksigen terendah yang dapat diartikan bahwa pasien tersebut memiliki kadar oksigenasi di bawah rentang normal.

Masalah yang terjadi pada pasien PPOK yang dapat menurunkan nilai saturasi oksigen adalah sesak nafas. Sesak nafas terjasi karena penyempitan pada pernafasan sehingga suplai oksigen sangat sedikit pada paru-paru. Penyempitan ini menyebabkan paruparu tidak dapat mengembang secara optimal, penurunan difusi oksigen sehingga terjadi penurunan saturasi oksigen. Hal ini sesuai dengan penelitian yang dilakukan oleh Kaur et al., (2018) yaitu sebanyak 52,5\% pasien PPOK mengalami sesak nafas dan sebesar 47,5 \% mengalami batuk dahak dan sesak nafas.

Tanda dan gelaja yang sering dialami pasien dengan PPOK adalah batuk berdahak dan sesak nafas. Hal ini disebabkan oleh sebagian besar penderita nya memiliki riwayat perokok aktif. Zat yang terkandung dalam rokok berupa partikel dan gas berbahaya yang 
jika dibiarkan dapat merusak paru-paru. Sebagian besar penderita PPOK memiliki riwayat merokok sebesar 60,7 \% dan 39,3\% tidak memiliki riwayat merokok (Wardani et al., 2019).

\section{Nilai Saturasi Oksigen Sesudah Relaksasi Nafas Dalam}

Hasil penelitian ini menunjukan bahwa setelah diberikan teknik relaksasi nafas dalam, didapatkan bahwa nilai saturasi oksigen tertinggi adalah $97 \%$ dan terendah adalah $90 \%$ dengan rerata saturasi oksigen sebesar 93,27\%. Hal ini dapat diartikan bahwa terdapat peningkatan nilai saturasi oksigen pada pasien PPOK antara setelah dan sebelum diberikan intervensi berupa teknik relaksasi nafas dalam.

Salah satu upaya rehabilitasi pada paru yaitu dengan latihan (exercise). Latihan pernafasan dapat melatih otot-otot diafragma yang digunakan untuk mengkompensasi kekurangan oksigen dan meningkatkan efisiensi pernafasan sehingga dapat mengurangi sesak nafas. Penelitian tentang senam yoga dalam mengurangi sesak nafas pada pasein PPOK dimana responden diberikan senam yoga selama 30 menit dapat mengatasi sesak nafas dan gangguan tidur (Zuriati \& Suriya, 2020). Penelitian lain tentang peningkatan nilai saturasi oksigen setelah diberikan posisi semi fowler selama 30 menit menunjukan rata-rata nilai saturasi oksigen 95,83 . Hal ini disebabkan oleh pengaturan posisi $45^{\circ}$ memungkinkan ekspansi dada lebih besar dan dapat membantu mengurangi kesulitan nafas serta meningkatkan saturasi oksigen (Astriani et al., 2021).

Penelitian serupa tentang penggunaan pursed lip breathing pada PPOK didapatkan hasil yaitu studi literatur yang digunakan pada 5 jurnal tentang pursed lip breathing berpengaruh pada evaluasi fisiologis, meningkatkan volume dinding dada dan kompartemennya serta pengurangan frekuensi pernafasan dibandingkan dengan pernafasan yang tenang (Kusumawati \& Yuniartika, 2020). Selanjutnya penelitian yang dilakukan pada 2 orang pasien PPOK diadapatkan hasil setelah diberikan penerapan posisi condong ke depan dan latihan pursed lip breathing selama 3 hari berturut-turut pada responden pertama Tn.A terdapat peningkatan saturasi oksigen yaitu dari $95 \%$ menjadi $98 \%$ dan pada responden kedua Tn.K juga terjadi peningkatan saturasi oksigen yaitu dari $94 \%$ menjadi 98\% (Cahyani et al., 2021).

Penelitian oleh Nuraini et al., (2019) pada Ny. S, umur 53 tahun didapatkan hasil frekuensi pernapasan $21 \mathrm{x} /$ menit. Teknik relaksasi diaphragmatic breathing exercise efektif dalam meningkatkan status pernapasan pada asuhan keperawatan PPOK. Penelitian serupa juga dilakukan oleh Rosyadi et al., (2019) pada 38 pasien PPOK yang dibagi menjadi kelompok kontrol dan intervensi. Hasil yang didapatkan yaitu sebanyak 7 orang mengalami dispnea berat setelah diberikan intervensi latihan pursed lip breathing, diaphragmatic breathing, dan upper limb stretching selama 4 minggu sebanyak 2 kali dalam 1 minggu menjadi dispnea sedang.

\section{Pemberian Relaksasi Nafas Dalam terhadap Saturasi Oksigen}

Hasil penelitian ini menunjukan bahwa terdapat perbedaan antara sebelum dan setelah pemberian teknik relaksasi nafas dalam terhadap saturasi oksigen pasien PPOK. Hal ini dapat diartikan bahwa teknik relaksasi nafas dalam berpengaruh terhadap peningkatan saturasi oksigen pada pasien PPOK. Hal ini sejalan dengan penelitian yang dilakukan oleh Yulia et al., (2019) yaitu sebanyak 30 orang yang mengalami asma didapatkan nilai saturasi oksigen meningkat menjadi 98,33 setelah diberikan intervensi nafas dalam selama 30 menit. Latihan nafas yang dilakukan berulang kali secara teratur dapat melatih otot-otot pernafasan, mengurangi beratnya gangguan pernafasan, menurunkan gejalan dyspnea, 
sehingga terjadi peningkatan perfusi dan perbaikan alveoli yang dapat meningkatkan kadar oksigen dalam paru sehingga terjadi peningkatan saturasi oksigen.

Penelitian yang dilakukan oleh Astrianiet al., (2020) rata-rata nilai saturasi oksigen meningkat dari 89,27 menjadi 94,53 setelah diberikan intervensi ballon blowing selama 510 menit selama 4 minggu. Ballon blowing sangat efektif untuk membantu ekspansi paru sehingga mampu mensuplai oksigen dan mengeluarkan karbondioksida yang terjebak dalam paru pada pasien dengan gangguan fungsi pernapasan. Hasil penelitian yang dilakukan oleh Junaidin et al., (2019) terdapat 112 artikel yang sesuai dengan kriteria inklusi. Untuk menghindari gangguan vital, menurunkan frekuensi nafas, meningkatkan nilai saturai oksigen pada PPOK dilakukan program latihan seperti pursed lip breathing dan meniup balon.

Hasil penelitian pada 30 sampel PPOK didapatkan rata-rata nilai saturasi oksigen meningkat dari 87,73 menjadi 89,97 setelah diberikan pernafasan diafragma selama 10 menit. Pernafasan diafragma dapat meningkatkan saturasi oksigen karena adanya peningkatan ventilasi yang diikuti oleh peningkatan perfusi sehingga kadar oksigen berkurang yang secara otomatis terjadi peningkatan nilai saturasi oksigen (Ain et al., 2019).

Penelitian oleh Tunik et al., (2020) pada 30 responden pasien PPOK RSUD dr. Soedomo Trenggalek ruang Flamboyan. Sebelum meniup balon pasien diminta untuk tarik nafas selama 3-4 detik lalu ditahan 2-3 detik setelah itu ditiupkan ke balon selama 5-8 detik. Intervensi ini dilakukan selama 1 minggu. Hasil yang didapat yaitu saat pre tes diapat nilai saturasi oksigen sebesar 90,8 setelah dilakukan posttest hari ke 3 nilai rata-rata menjadi 92,2. Pada hari ke 7 nilai rata-rata saturasi oksigen menjadi 93,4. Hal ini menunjukkan bahwa nilai saturasi oksigen meningkat setelah diberikan breathing relaxation dengan menggunakan teknik ballon blowing.

Relaksasi nafas dalam dapat melatih otot-otot diafragma yang digunakan untuk mengkompensasi kekurangan oksigen dan meningkatkan efisiensi pernafasan sehingga dapat mengurangi sesak nafas. Latihan nafas yang dilakukan berulang kali secara teratur dapat melatih otot-otot pernafasan, mengurangi beratnya gangguan pernafasan, menurunkan gejalan dyspnea, sehingga terjadi peningkatan perfusi dan perbaikan alveoli yang dapat meningkatkan kadar oksigen dalam paru sehingga terjadi peningkatan saturasi oksigen.

\section{SIMPULAN}

Mayoritas responden berumur diatas 30 tahun, sebagian besar responden berjenis kelamin laki-laki. Ada pengaruh teknik relaksasi nafas dalam terhadap peningkatan saturasi oksigen pada pasien PPOK.

\section{SARAN}

Diharapkan dapat menambah wawasan keilmuan keperawatan tentang pengaruh teknik relaksasi nafas dalam terhadap peningkatan saturasi oksigen pada pasien PPOK. Selanjutnya, hal tersebut dapat menjadi informasi dasar dalam kurikulum pembelajaran yang tepat mengenai masalah pelayanan keperawatan pada jenjang pendidikan keperawatan. Bagi masyarakat dapat menerapkan pengetahuan tentang teknik relaksasi nafas dalam untuk meningkatkan nilai saturasi oksigen. Bagi peneliti selanjutnya dapat digunakan sebagai acuan atau gambaran informasi untuk pelaksanaan penelitian lebih lanjut berkaitan tentang pengaruh teknik relaksasi nafas dalam terhadap peningkatan saturasi oksigen pada pasien PPOK. 


\section{DAFTAR PUSTAKA}

Ain, H., Anantasari, R., \& Fahmi, M. F. N. (2019). Pernafasan Diafragma Meningkatkan Saturasi Oksigen pada Pasien PPOK di RSUD Soedarsono Pasuruan. Prosiding Seminar Nasional Hasil Penelitian dan Pengabdian Masyarakat Seri Ke-3 Tahun 2019, 53-61

Astriani, N. M. D. Y., Ariana, P. A., Dewi, P. I. S., Heri, M., \& Cita, E. E. (2020). PKM: Pelatihan Relaksasi Nafas Ballon Blowing untuk Meningkatkan Saturasi Oksigen pada Warga Desa Bungkulan Singaraja. VIVABIO: Jurnal Pengabdian Multidisiplin, 2(2), 1. https://doi.org/10.35799/vivabio.2.2.2020.30279

Astriani, N. M. D. Y., Aryawan, K. Y., \& Heri, M. (2020). Teknik Clapping dan Vibrasi Meningkatkan Saturasi Oksigen Pasien PPOK. Jurnal Keperawatan Silampari, 4(1), 248-256. https://doi.org/10.31539/jks.v4i1.1767

Astriani, N. M. D. Y., Dewi, P. I. S., \& Yanti, K. H. (2020). Relaksasi Pernafasan dengan Teknik Ballon Blowing terhadap Peningkatan Saturasi Oksigen pada Pasien PPOK. Jurnal Keperawatan Silampari, $\quad 3(2), \quad 426-435$. https://doi.org/10.31539/jks.v3i2.1049

Astriani, N. M. D. Y., Sandy, P. W. S. J., Putra, M. M., \& Heri, M. (2021). Pemberian Posisi Semi Fowler Meningkatkan Saturasi Oksigen Pasien PPOK. Journal of Telenursing (JOTING), 3(1), 128-135. https://doi.org/10.31539/joting.v3i1.2113

Balitbangkes. (2019). Laporan Provinsi Bali Riskesdas 2018. In Lembaga Penerbit Badan Penelitian dan Pengembangan Kesehatan

Cahyani, R. P., Pujiarto, P., \& Putri, N. W. (2021). Asuhan Keperawatan Pasien PPOK Menggunakan Posisi Condong ke Depan dan Latihan Pursed Lip Breathing untuk Meningkatkan Saturasi Oksigen. Madago Nursing Journal, 1(2), 37-43. https://doi.org/10.33860/mnj.v1i2.277

Harsismanto, J., Padila, P., Andri, J., Andrianto, M. B., \& Yanti, L. (2020). Frekuensi Pernafasan Anak Penderita Asma Menggunakan Intervensi Tiup Super Bubbles dan Meniup Baling Baling Bambu. Journal of Telenursing (JOTING), 2(2), 119-126. https://doi.org/https://doi.org/10.31539/joting.v2i2.1409

Junaidin, J., Syam, Y., \& Irwan, A. M. (2019). Pengaruh Pursed Lip Breathing dan Meniup Balon terhadap Kekuatan Otot Pernapasan, Saturasi Oksigen dan Respiratory Rate pada Pasien Ppok. Jurnal Ilmiah Keperawatan (Scientific Journal of Nursing), 5(1), 31-39. https://doi.org/10.33023/jikep.v5i1.211

Kaur, B., Parhusip, R. S., \& Sinurat, P. P. O. (2018). Gambaran Diagnostik dan Penatalaksanaan Pasien Penyakit Paru Obstruksi Kronik. Jurnal Kedokteran Methodist, 11(1), 10-13. http://ojs.lppmmethodistmedan.net/index.php/JKM/article/view/329

Kusumawati, R. D., \& Yuniartika, W. (2020). Penggunaan Pursed Lip Breathing pada Penyakit Paru Obstruktif Kronik ( PPOK ). The 12th University Research Colloqium $2020 \quad$ Universitas 'Aisyiyah Surakarta, 73-83. http://repository.urecol.org/index.php/proceeding/article/view/1125

Lilyana, M. T. A. (2017). Manajemen Nonfarmakologis Terapi bagi Pasien PPOK. Jurnal Ners Lentera, $5(2)$, 178-182. http://jurnal.wima.ac.id/index.php/NERS/article/view/1799

Lukito, A. (2019). Hubungan Faktor Resiko dengan Kejadian pada Penyakit Paru Obstruksi Kronik di Puskesmas Mandala. Jurnal Penelitian Keperawatan Medik, 1(2), 43-47. http://ejournal.delihusada.ac.id/index.php/JPKM 
Maunaturrohmah, A., \& Yuswatiningsih, E. (2018). Terapi Diafragma untuk Pasien Penyakit Paru Obstruktif Kronik (PPOK) (A. Dr. Rifa'atul Laila Mahmudah, M.Farm.Klin. (ed.)). Stikes Majapahit Mojokerto. http://ejournal.stikesmajapahit.ac.id/index.php/EBook/article/view/313

Nuraini, S., Suyadi, \& Pamungkas, U. U. (2019). Teknik Relaksasi Diaphragmatic Breathing Exercise dalam Meningkatkan Status Pernapasan pada Asuhan Keperawatan Penyakit Paru Obstruktif Kronik (Ppok). Jurnal Keperawatan CARE, 9(2), 1-11. http://ejurnal.akperyappi.ac.id/index.php/files/article/view/97

Padila, P., Febriawati, H., Andri, J., \& Dori, R. A. (2019). Perawatan Infeksi Saluran Pernafasan Akut (ISPA) pada Balita. Jurnal Kesmas Asclepius, 1(1), 25-34. https://doi.org/https://doi.org/10.31539/jka.v1i1.526

Padila, P., Harsismato, J., Yanti, L., Setiawati, S., \& Andri, J. (2020). Meniup Super Bubbles dan Baling-Baling Bamboo pada Anak Penderita Pneumonia. Jurnal Keperawatan Silampari, 4(1), https://doi.org/https://doi.org/10.31539/jks.v4i1.1545

112-119.

Rosyadi, I., Djafri, D., \& Rahman, D. (2019). Pengaruh Pemberian Pursed Lip-Breathing, Diaphragmatic Breathing, dan Upper Limb Stretching terhadap Skala Dispnea pada Pasien PPOK. NERS Jurnal Keperawatan, 15(2), 103. https://doi.org/10.25077/njk.15.2.103-109.2019

Tarigan, A. P. S., \& Juliandi, J. (2018). Pernafasan Pursed Lip Breathing Meningkatkan Saturasi Oksigen Penderita Penyakit Paru Obstruktif Kronis (PPOK) Derajat II. Jurnal Keperawatan Indonesia, $\quad 1(2), \quad 39-46$. http://114.7.97.221/index.php/Keperawatan/article/view/426

Tunik, T., Niningasih, R., \& Edi, Y. (2020). Pengaruh Breathing Relaxation dengan Teknik Balloon Blowing terhadap Saturasi Okesigen Pasien PPOK. Jurnal Pendidikan Kesehatan, 9(2), 193-199. https://doi.org/https://doi.org/10.31290/jpk.v9i2.2031

Wardani, E. D. K., Faidah, N., \& Nugroho, T. W. (2019). Efektivitas Diaphragmatic Breathing Exercise terhadap Peningkatan Saturasi Oksigen Pasien PPOK di Ruang Melati I dan Melati II RSUD dr.Loekmonohadi Kudus. Prosiding HEFA 4th 2019, 60-67. http://prosiding.stikescendekiautamakudus.ac.id/index.php//article/view/357

Yulia, A., Dahrizal, D., \& Lestari, W. (2019). Pengaruh Nafas Dalam dan Posisi terhadap Saturasi Oksigen dan Frekuensi Nafas pada Pasien Asma. Jurnal Keperawatan Raflesia, 1(1), 67-75. https://doi.org/10.33088/jkr.v1i1.398

Zuriati, Z., \& Suriya, M. (2020). Implementasi Senam Yoga dalam Mengurangi Sesak Nafas pada Pasien PPOK. Jurnal Pengabdian Harapan Ibu (JPHI), 2(2), 43. https://doi.org/10.30644/jphi.v2i2.438 